\title{
Factors Of Success And Failure Of The Cities Through Mediation In The High Judgment Region Of Banten
}

\author{
Karmawan \\ \{karmawan@unis.ac.id\} \\ Universitas Islam Syekh-Yusuf, Jl. Maulana Yusuf Babakan Kota Tangerang, Indonesia

\begin{abstract}
The purpose of this study is to analyze the settlement of Islamic civil cases through mediation by analyzing the factors that determine the success and failure of cases resolved through mediation in the jurisdiction of the Banten High Court. This research is a kind of descriptive legal research using a qualitative approach. The type of data used is primary data and secondary data. Data sources used are primary data sources and secondary data sources. The results of this study include; 1) The failure factor; the parties did not want to make peace, the lack of knowledge of judges, and the role of advocates did not support peace; 2) success factors; the good faith of the parties, the type of dispute is easy, and the mediating judge helps reach an agreement. The conclusion of this research is that the more settlement of cases through mediation, the higher the level of justice perceived, and the fulfillment of the principle of justice that is simple, fast and low-cost promoting justice in society.
\end{abstract}

Keywords: Success, failure, and Mediation

\section{Introduction}

Mediation is a form of case settlement practice outside the court that has been institutionalized among Indonesian people. It can even be used by courts, both general courts and religious courts, as a breakthrough in the case resolution process. Integration of mediation as a court proceeding process will have potential strength, even as an alternative means of resolving cases that prioritize economic elements in court practice, both in terms of funding and time that can be minimized.[1] Even mediation provides convenience and benefits to the parties that litigate a win-win solution,[2] not to make the parties to the case of a win-lose case in court. In addition, the implementation of mediation conducted by the court is expected to be able to overcome the problem of the accumulation of cases that have occurred so far.

The problem that arises if mediation as a way to settle disputes turn into judicial competence, will it not lead to the addition and accumulation of cases in the court, the initiative and role of the parties who litigate is greater than judicial judges who are more passive and only facilitate the litigants the. Thus, at least if an agreement of the parties is reached through mediation, the case can be settled at the Court level, and the addition and stacking of case files does not occur.[3]

Based on the report of the Supreme Court of the Republic of Indonesia, cases entered in 2013 out of 5,573 total cases mediated in the general court environment, the success rate was 1,194 cases or $21.4 \%$. While in the religious court environment the number of 25,338 cases were mediated, the success rate of mediation was 148,241 cases or $17.08 \%$. In 2014 , there were 7,046 cases mediated in the general court environment, with a success rate of 374 cases 
or $5.3 \%$. Whereas in the religious court environment, 132,223 cases were mediated, the success rate of mediation was 32 cases or $24.7 \%$. The cases that entered in 2015 were 8,023 cases mediated in the general court environment, with a success rate of 1,247 or $15.54 \%$. Whereas in the religious court environment the number of 6,046 cases were mediated, the success rate of mediation was 1,019 cases or $16.85 \%$.[4] This percentage shows that the community still does not use much mediation in court. It shows that the Supreme Court will always face the problem of case settlement, this is because the number of cases decided is relatively the same as the number of cases that have just entered, as if there was stagnation / stagnation in the settlement of a successful case mediated.[5]

Mediation conducted by the Religious Courts in the Banten High Religious Courts area as an alternative case settlement with the help of mediators attempts to prioritize the court process faster and lower costs, and can provide significant changes to the cases that enter the Religious Court and as access to find a satisfactory settlement, meet a sense of justice for all parties. The selection of the Religious Court research in the Banten High Court area is an object of research based on three things. First, the implementation of mediation at the Religious Courts in the jurisdiction of the Banten High Religion Court has been integrated as a proceeding process at the Religious Courts based on the case areas of the parties. Second, judges within the Religious Courts in the Banten High Court area carry out their functions in an effort to encourage the effectiveness of the implementation of mediation. Third, the mediator's approach and strategy in dealing with the parties, efforts to produce a peace agreement, especially in Islamic civil cases including divorce, hadhonah, joint assets, inheritance and shari'ah economic matters. Fourth, the success and failure of mediated cases is a factor in the ability of mediators to handle the cases of the parties.

\section{Research Methods}

\subsection{Types of Research and Approaches}

This type of research is a qualitative study according to Holmes Rolston this method is an attempt to approach and get the truth.[6] This study uses a socio-legal approach, which only places the law as a social phenomenon. That is why this research is social in nature related to law.[7] Through this approach, this research tries to find social facts to make judges' decisions more realistic and not only applied in the processes of creating law (in-absracto) but also applied in processes of legal discovery (in-concreto).[8]

This research was also combined using a statute approach which was examined in the literal interpretation contained in the law (PerMa No. 1 of 2008) which was then analyzed in theory and practice. In other words, this study will try to analyze law in the book (theory) with law in practice.

In addition this study is also complemented by a comparative study between the implementation of the judge's study as a legal inventor with legal actions. That way this study uses a comparative approach. This aims to identify the factors causing the success and failure of mediation in terms of deciding cases in the Religious Courts within the jurisdiction of the Banten High Religious Court.

\subsection{Data source}

Data collected in this research are: primary and secondary sources. Primary data is directly obtained from the first data source at the research location or research object, while 
secondary data is data obtained from the second source or secondary source of the required data.[9]

1. The primary sources for this study were the decision of the judge of the Religious Court, PerMA No. 1 of 2008, Law no. 7 of 1989, Law No. 14 of 1970, Compilation of Islamic Law (KHI), Law No. 1 of 1974 and interviews.

2. Secondary sources, (secondary sources), because this research was conducted by examining library materials, then categorized as normative research for it was carried out through library research on secondary data consisting of books relevant to the theme of the study.

\subsection{Data Collection}

In conducting this research, the author uses several data collection techniques related to the problem under study. The data collection techniques are literature study, interview with the judge concerned, as well as a study of the decisions of the Religious Court's decision:

1. Literature research, this research is intended to find out and understand the basic concepts regarding Religious Court judges both according to law in Indonesia and the classical traditions in Islamic Jurisprudence through books of research results, scientific journals, newspapers, as well as all studies related to this study .

2. Examining decision documents produced by Religious Court judges. This verdict is studied carefully and deeply so that the pattern and method of the religious judge's method are seen.

3. Interviews, conducted with respondents namely judges in the Religious Court.

\subsection{Data Analysis}

This research uses content analysis method that is analyzing data about objects studied according to content, which relates to the law in the form of decisions in the perspective of rules in Islamic law then in terms of legal sources in the form of the Koran and the Sunnah of the Prophet and the sources of applicable law in Indonesia, such as Law No. 1 of 1974 concerning marriage, Compilation of Islamic law, Law no. 14 of 1970 concerning judicial authority, Law no. 7 of 1989 concerning the authority of the Religious Courts.

\section{Results And Discussion}

Based on the author's observations in the field, that the mediation process carried out by the Religious Court mediators in the Banten High Court District sometimes succeeded and sometimes found failure. the success of the mediation process depends on the parties to the litigation, because they want to end their case in good faith through peace, so that the case does not need to be continued in a court decision, and a peace deed can be made according to the agreement agreed upon by both parties to the case. The parties cannot appeal because the legal power of peace agreement is the same as the decision made by the Religious Court. While failures can also be found in the mediation process as seen from the parties who litigate sometimes do not want to make peace even do not want to attend the mediation process, and sometimes the failure is triggered by parties who do not want to succumb to each other making it difficult for mediators to work for peace.

Mediation which is carried out in the area of the Banten High Court as an alternative case settlement with the help of mediators attempts to prioritize the process of proceedings faster 
and cheaper, and can provide significant changes to the cases that enter the Religious Court and as access to find a satisfactory solution, meet a sense of justice all parties.

\section{Conclusions}

Factors for the success of cases mediated in the area of the Banten High Court include; first, the parties in good faith, second, the type of dispute is easily resolved, the mediating judge helps the Parties reach an agreement.

Factors of case failure mediated in the area of the Banten High Religion court include; first the parties do not want to make peace, do not want to give in to each other's perceptions and want a decision from the Religious Court, so it is difficult to produce a peace agreement, the absence of the parties. Second, the lack of knowledge of judges, Third, the role of advocates does not support the occurrence of mediation.

\section{Reference}

[1] Lawrence R. Freedman \& Michael L. Prigoff, "Confidentiality in Mediation: The Need for Protection," J. Disput. Resolut., vol. 98, no. 2, p. 37, 1986.

[2] R. E. Margulies, “How To Win In Mediation,” Lawyer The. New Jersey, 2002.

[3] J. Lande, "Prosedure for Building Quality Into Court Mediation Programs," J. Altern. to High Cost Litig., p. 22, 1995.

[4] M. A. R. Indonesia, "Laporan tahunan Mahkamah Agung Republik Indonesia tahun 2013-2015,” 2015.

[5] A. R. Halim, Hukum Acara Perdata dalam Tanya-Jawab. Jakarta: Ghalia Indonesia, 2005.

[6] H. Rolston, Science and Religion: A Critical Survey. New York: ColoradoState University.

[7] P. M. Marzuki, Penelitian Hukum. Jakarta: Kencana, 2007.

[8] B. Sunggono, Metodologi Penelitian Hukum. Jakarta: PT. Raja Grapindo Persada, 2007.

[9] M. B. Bungin, Metode Penelitian Kuantitatif. Jakarta: Kencana, 2005. 